\title{
Studies of
}

\section{Evaporation}

GEOLOGICAL SURVEY PROFESSIONAL PAPER 272

This volume was published as separate chapters $A-H$

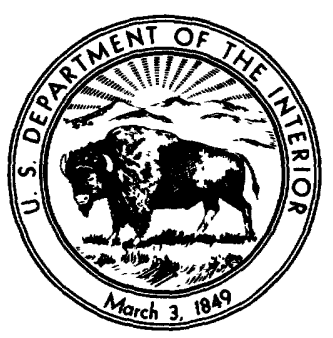


UNITED STATES DEPARTMENT OF THE INTERIOR

STEWART L. UDALL, Secretary

GEOLOGIGAL SURVEY

William T. Pecora, Director 


\section{CONTENTS}

[Letters designate the soparately published chapters]

(A) The effect of salinity on evaporation, by G. Earl Harbeck, Jr.-

(B) The effect of the addition of heat from a powerplant on the thermal structure and evaporation of Lake Colorado City, Texas, by G. Earl Harbeck, Jr., G. E. Koberg, and G. H. Hughes.

(C) Review of literature on evaporation suppression, by George B. Magin, Jr., and Lois E. Randall

(D) Evaporation from the 17 Western States, by J. Stuart Meyers.

(E) A practical field technique for measuring reservoir evaporation utilizing mass-transfer theory, by G. Earl Harbeck, Jr_-

F) Methods to compute long-wave radiation from the atmosphere and reflected solar radiation from a water surface, by Gordon E. Koberg . . .

(G) Evaporation study in a humid region, Lake Michie, North Carolina, by J. F. Turner, Jr...

(H) Analysis of techniques used to measure evaporation from Salton Sea, California, by G. H. Hughes............... 


\section{The Effect of}

Salinity on

Evaporation

By G. EARL HARBECK, JR.

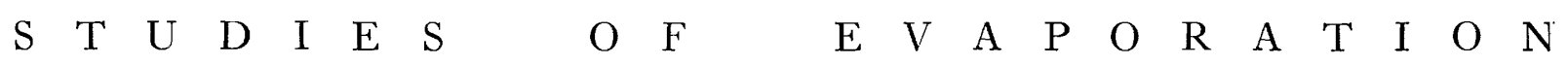

GEOLOGICAL SURVEY PROFESIONAL PAPER 272-A

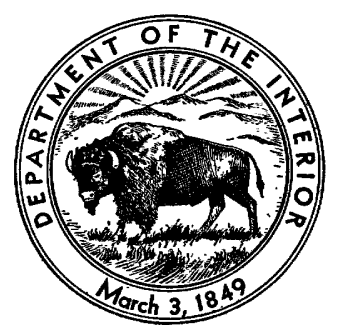

UNITED STATES GOVERNMENT PRINTING OFFICE, WASHINGTON : 1955 


\section{UNITED STATES DEPARTMENT OF THE INTERIOR \\ Douglas McKay, Secretary}

GEOLOGIGAL SURVEY

W. E. Wrather, Director

For sale by the Superintendent of Documents, U. S. Government Printing Office Washington 25, D. C. - Price 15 cents (paper cover) 


\section{PREFACE}

This report on the effect of salinity on evaporation was prepared in the Water Resources Division of the Geological Survey under the administrative supervision of R. W. Davenport, Chief, Technical Coordination Branch, and the technical guidance of W. B. Langbein.

The advice and assistance of W. W. Hastings, Quality of Water Branch, who also furnished the results of the chemical analyses, is greatly appreciated.

This report is part of the applied research investigations of evaporation jointly sponsored by the C.S. Bureau of Reclamation, the U. S. Weather Bureau, and the U. S. Geological Survey. 


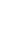




\section{CONTENTS}

Abstract._.

ntroduction $\ldots \ldots \ldots \ldots$

Effect of salinity on saturation vapor pressure.

Effect of salinity on evaporation

Tomparison with data obtained by Adams $\ldots \ldots \ldots$

selected bibliography

\section{ILLUSTRATIONS}

IGURE 1. Relation between salinity and reduction in saturation vapor pressure at $15^{\circ} \mathrm{C} \ldots \ldots$

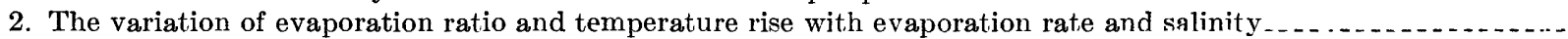

\section{TABLE}

TABLE 1. Equivalents per million, and percentage equivalents per million of various constituents in natural waters as indicated by selected analyses 
, 


\section{STUDIES OF EVAPORATION}

\section{THE EFFECT OF SALINITY ON EVAPORATION}

By G. Earl Harbeck, Jr.

\begin{abstract}
The effect of salinity is to reduce evaporation but at the same time to increase the energy returned to the atmosphere by other physical processes, so that under equilibrium conditions a saline solution reaches a temperature higher than that of pure water. Because of the many variables, of which some are interrelated, it is impossible to define a simple relationship between salinity and the decrease in evaporation. The theory presented in this report is general, and for any given rate of evaporation from pure water, the effect of salinity on evaporation and the attendant temperature rise can be determined on the basis of measurements of air and water temperatures, humidity, and atmospheric pressure.
\end{abstract}

\section{INTRODUCTION}

It has long been known that evaporation from a free water surface is reduced by salinity. Several investigators have presented the results of experimental determinations of the reduction in evaporation with increasing salinity. Lee (1927) compared the evaporation from distilled water with evaporation from Owens Lake brine of varying specific gravities, and presented a chart showing that up to a certain limit the ratio of evaporation of brine to that of distilled water decreased about 1 percent for a change in specific gravity of 0.01 . Young (1947) presented the results of experiments using varying concentrations of sodium chloride, and his findings did not differ greatly from those of Lee.

The effect of dissolved solids is, of course, to reduce the saturation vapor pressure of the solution. In almost all of the equations based on the theory of mass-transfer or turbulent transport of energy and in nearly all empirical evaporation equations, evaporation is directly proportional to the vapor-pressure difference. Among these are the equations proposed by Sverdrup (1937) and Sutton (1949), which were among those tested during the Lake Hefner studies (U. S. Geol. Survey, 1952, p. 54-61). Although there is still diversity of opinion concerning wind laws, atmospheric stability, and certain other aspects of the mass-transfer theory, there seems to be general agreement that with other variables held constant, evaporation is directly proportional to the difference between the vapor pressure of the air in contact with the water (usually taken as the saturation vapor pressure of air at the temperature of the water surface) and the rapor pressure of the air at some height.

\section{EFFECT OF SALINITY ON SATURATION VAPOR} PRESSURE

Unfortunately, experimental data on the effert of various salts on saturation vapor pressure, in varying concentrations and at different temperatures are incomplete. Sverdrup, Johnson, and Fleming (1942) presented rather complete data for sea water (salinity $35,000 \mathrm{ppm})^{1}$ at temperatures from $-2^{\circ} \mathrm{C}$ to $32^{\circ} \mathrm{C}$. For other concentrations the International Critical Tables (National Research Council, 1928) provided data for solutions of other salts. (See fig. 1.) Within the range of temperatures experienced in natural ws,ters, the percent reduction in saturation vapor pressure is affected only slightly by temperature. A temperature of $15^{\circ} \mathrm{C}$ was therefore arbitrarily chosen as the standard temperature at which to compare the effects of the different salts. Data for sodium chloride, magnesium chloride, and potassium chloride cover a fairly wide range of concentrations as shown by the light solid lines of figure 1. Data for sodium sulfate and sodium carbonate cover a limited range of concentrations. Extrapolations in the direction of decreasing salinity were made by auxiliary plotting on arithmetic coordinates. The other salts commonly found in natural waters, calcium bicarbonate, calcium sulfate, and magnesium bicarbonate, are only slightly solub!e so that it is not surprising that data are lacking on their effect on reduction in saturation vapor pressure. Data on the effect of magnesium sulfate are available only at temperatures of $50^{\circ} \mathrm{C}$ and above.

In order to define a curve for average natural waters (see fig. 1), approximate percentages of värious salts

1 Salinity as the term is used by oceanographers is the total amount of solid material in grams contained in one kilogram of sea water, or in parts per thousand. Published analyses of natural inland waters show dissolved solids in parts per million, $v^{r}$ hich is the unit of measure used throughout this discussion. 


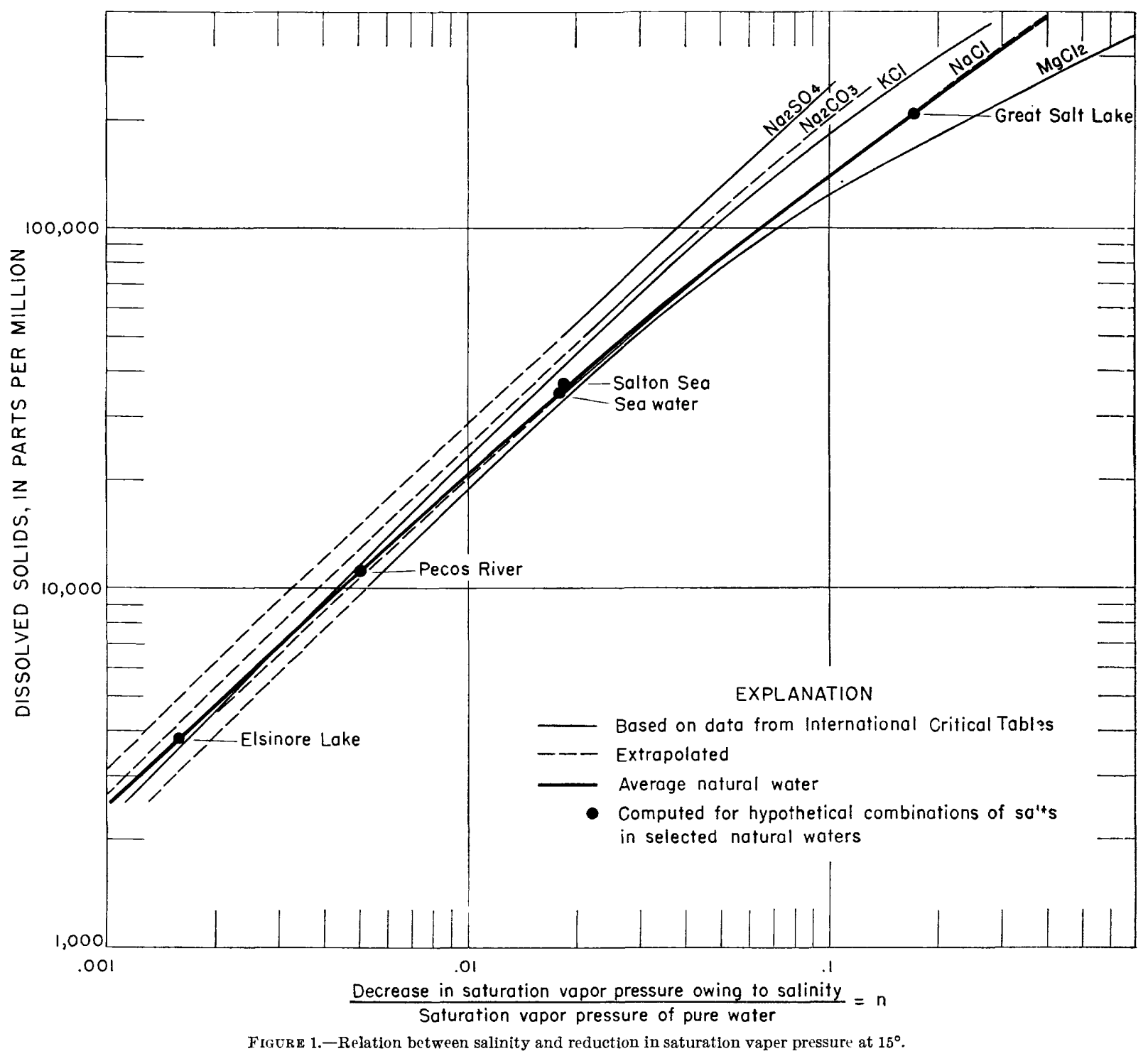

in hypothetical combination were computed for certain selected natural waters, based on the data given in table 1. These percentages were used as weighting factors in computing the reduction in saturation vapor pressure for the various samples of natural water. When the total amount of dissolved solids is small, calcium and magnesium salts form a relatively large part of the total. The percentage of sodium chloride, however, often increases in waters with greater dissolved solids. About 87 percent of the dissolved solids in Great Salt Lake is sodium chloride, with relatively small proportions of magnesium sulfate and magnesium chloride. This is to be expected because of the much greater solubility of sodium chloride as compared with the calcium salts. Thus, the curve for natural water shown in figure 1 closely approximates the sodium chloride curve at high concentrations. However, impounded return flow from irrigated lands in sedimentary deposits in the semiarid west is frequently high in sodium sulfate, and the chloride content may be insignificant. In this instance, the curve for average natural waters shown in figure 1 would not be applicable, and the curve shown for sodium sulfate would be more nearly correct.

Unfortunately figure 1 cannot be used directly for the computation of the reduction in eveporation owing to salinity. The reduction in saturation pressure shown in figure 1 applies to a saline solution at the same temperature as pure water $\left(15^{\circ} \mathrm{C}\right.$ in this illustration). If a pan of brine and a pan of pure water are similarly exposed, the temperature of the brine will be higher than that of the pure water after equilibrium has been reached. If the amount of incoming enargy is assumed to be the same for both pans, the amount of outgoing energy must also be the same. Because the saturation vapor pressure of the brine (and thereby the vapor 
TABLE 1.-Equivalents per million (epm), and percentage equivalents per million of various constituents in natural waters as ind ated by selected analyses ${ }^{3}$

\begin{tabular}{|c|c|c|c|c|c|c|c|c|c|c|c|c|c|c|}
\hline Ion & $\begin{array}{l}\text { Lake } M \\
\text { Nev. ( }\end{array}$ & $\begin{array}{l}\text { Ariz.- } \\
\text { ppm) }\end{array}$ & $\begin{array}{c}\text { Maywo } \\
\text { ter su } \\
\text { ppm) }\end{array}$ & 11., wa- & $\begin{array}{r}\text { EIsinore I } \\
(3,800\end{array}$ & $\begin{array}{l}\text { e, Calif. } \\
\text { m) }\end{array}$ & $\begin{array}{c}\text { Pecos } \\
\text { G ir } \\
(11,000\end{array}$ & $\begin{array}{l}\mathrm{r} \\
\mathrm{n}) \\
\mathrm{Tex}\end{array}$ & $\begin{array}{r}\text { Sed } \\
(35,0\end{array}$ & & $\begin{array}{l}\text { Salton } \\
\quad(37,0\end{array}$ & $\begin{array}{l}\text { Calif. } \\
\text { m) }\end{array}$ & $\begin{array}{c}\text { Great } \\
\text { Utah } \\
\text { ppm) }\end{array}$ & $\begin{array}{r}\text { Lake, } \\
10,000\end{array}$ \\
\hline $\begin{array}{l}\mathrm{Ca} \\
\mathrm{Mg} \\
\mathrm{Na}+\mathrm{K} \\
\mathrm{Fe}\end{array}$ & $\begin{array}{l}\text { epm } \\
\text { 4. } 04 \\
2.14 \\
3.47 \\
0\end{array}$ & $\begin{array}{r}\text { Percent } \\
\text { epm } \\
42 \\
22 \\
36 \\
0\end{array}$ & $\begin{array}{l}\text { epm } \\
4.86 \\
2.25 \\
8.54 \\
.01\end{array}$ & 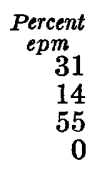 & $\begin{array}{l}\text { epm } \\
0.65 \\
2.06 \\
53.62 \\
0\end{array}$ & $\begin{array}{r}\text { Percent } \\
\text { epm } \\
1 \\
4 \\
95 \\
0\end{array}$ & $\begin{array}{r}\text { epm } \\
36.8 \\
32.2 \\
113.1 \\
.7\end{array}$ & $\begin{array}{r}\text { Percent } \\
\text { epm } \\
20 \\
18 \\
62 \\
0\end{array}$ & $\begin{array}{r}\text { epm } \\
21 \\
107 \\
476 \\
0\end{array}$ & $\begin{array}{r}\text { Percent } \\
\text { epm } \\
3 \\
18 \\
79 \\
0\end{array}$ & $\begin{array}{r}e p m \\
32 \\
6 \\
602 \\
0\end{array}$ & $\begin{array}{r}\text { Percent } \\
\text { epm } \\
5 \\
1 \\
94 \\
0\end{array}$ & $\begin{array}{r}\text { epm } \\
18 \\
478 \\
3,112 \\
0\end{array}$ & $\begin{array}{r}P \text { Prcent } \\
\text { epm } \\
1 \\
1 \\
13 \\
86 \\
0\end{array}$ \\
\hline Total & 9.65 & 100 & 15. 66 & 100 & 56. 33 & 100 & 182.8 & 100 & 604 & 100 & 640 & 100 & 3,608 & 100 \\
\hline $\begin{array}{l}\mathrm{HCO}_{3} \\
\mathrm{SO}_{4} \\
\mathrm{Cl}_{2} \\
\mathrm{NO}_{3}\end{array}$ & $\begin{array}{l}2.06 \\
5.93 \\
1.66 \\
0\end{array}$ & $\begin{array}{r}21 \\
62 \\
17 \\
0\end{array}$ & $\begin{array}{l}5.39 \\
2.48 \\
7.79 \\
0\end{array}$ & $\begin{array}{r}34 \\
16 \\
50 \\
0\end{array}$ & $\begin{array}{r}18.99 \\
4.29 \\
33.05 \\
0\end{array}$ & $\begin{array}{r}34 \\
7 \\
59 \\
0\end{array}$ & $\begin{array}{r}2.5 \\
63.7 \\
116.6 \\
0\end{array}$ & $\begin{array}{r}1 \\
35 \\
64 \\
0\end{array}$ & $\begin{array}{r}22 \\
56 \\
546 \\
0\end{array}$ & $\begin{array}{r}0 \\
9 \\
91 \\
0\end{array}$ & $\begin{array}{r}35 \\
114 \\
491 \\
0\end{array}$ & $\begin{array}{r}5 \\
18 \\
77 \\
0\end{array}$ & $\begin{array}{r}4 \\
238 \\
3,366 \\
0\end{array}$ & $\begin{array}{r}0 \\
7 \\
93 \\
0\end{array}$ \\
\hline Total & 9. 65 & 100 & 15. 66 & 100 & 56. 33 & 100 & 182.8 & 100 & 604 & 100 & 640 & 100 & 3,608 & 100 \\
\hline
\end{tabular}

1 Analyses of Elsinore Lake and Salton Sea by Department of Agriculture; otbers by Geological Survey.

pressure difference) is less than for water, the amount of energy utilized for evaporation is also less. The temperature of the brine must rise until the energy made available by the decrease in evaporation can be returned to the atmosphere by means of other physical processes. Evaporation from the brine will be less, although greater than if the two fluids were at the same temperature. It is therefore necessary to determine the effect of salinity and other factors on the temperature rise of the brine.

\section{EFFECT OF SALINITY ON EVAPORATION}

The energy budget for a body of water may be expressed as follows:

$$
Q_{s}-Q_{r}+Q_{a}-Q_{a r}-Q_{b s}-Q_{e}-Q_{h}+Q_{v}-Q_{w}=Q_{\vartheta}
$$

in which $Q_{s}=$ solar radiation incident to the water surface

$Q_{r}=$ reflected solar radiation

$Q_{a}=$ incoming long-wave radiation from the atmosphere

$Q_{a r}=$ reflected long-wave radiation

$Q_{b s}=$ long-wave radiation emitted by the body of water

$Q_{e}=$ energy utilized by evaporation

$Q_{h}=$ energy conducted from the body of water as sensible heat

$Q_{v}=$ net energy advected into the body of water

$Q_{w}=$ energy advected by the evaporated water

$Q_{\vartheta}=$ change in energy stored in the body of water

Consider two identical insulated shallow pans similarly exposed, one containing pure water, the other containing brine. Each will have an energy budget, and many items will be the same for both pans. If the exposures are the same, it may be assumed that the solar and atmospheric radiation received by both pans will bo the same. The amount of incoming solar radiation that is reflected depends on sun altitude and cloud cover, according to Anderson (U. S. Geol. Survey, 1952, p. 87) and should be the same for both pans. Long-wave radiation reflected by the body of water and emitted by the body of water depends only on the emissivity. A study made by Gier and Dunkle (U. S. Geol. Survey, 1952 , p. 96-98) indicated that the emissivity of water is 0.970 (reflectivity $=1-$ emissivity $=0.030$ when sc urce and water temperatures are equal), and it is independent of water temperature and dissolved solids. Although the maximum salinity of any water sample tested was $33,420 \mathrm{ppm}$, there is no evidence to indicate that emissivity does not remain constant for even greater amounts of dissolved solids. If no water is added to either pan, the advected energy term is zero for both pans. If the pans are very shallow, it may be safely assumed that at least for short periods of time, the changes in energy storage, on a unit-area basis, are negligible.

After equilibrium has been attained, the sum of certain items in the energy budget for the pan of pure water may be equated to the sum of the same items ir. the energy budget for the pan of brine, as follows:

$$
Q_{b s}+Q_{e}+Q_{h}+Q_{w}=Q_{b s}^{\prime}+Q_{e}^{\prime}+Q_{h}^{\prime}+Q_{w}^{\prime}
$$

Throughout this discussion the symbols with primes refer to the pan of brine and the symbols without primes refer to the pan of pure water.

Combinations of various terms in equation (2) may be evaluated using certain familiar relations, as follows (units: cal $\mathrm{cm}^{-2} \mathrm{day}^{-1}$ )

$$
Q_{b s}^{\prime}-Q_{b s}=0.970 \sigma\left[\left(T^{\prime}{ }_{n}+273\right)^{4}-\left(T_{0}+273\right)^{4}\right]
$$


in which $\sigma=$ Stefan-Boltzman constant for black-body radiation

$=1.171 \times 10^{-7} \mathrm{cal} \mathrm{cm}^{-2} \mathrm{deg}^{-4} \mathrm{day}^{-1}$

$T_{0}=$ water surface temperature in degrees $\mathrm{C}$

$$
Q^{\prime}{ }_{e}-Q_{e}=\rho E^{\prime} L^{\prime}-\rho E L
$$

in which $\rho=$ average density of evaporated water $(\doteq 1$ $\mathrm{gm} \mathrm{cm}^{-3}$ )

$E=$ average daily evaporation in $\mathrm{gm} \mathrm{cm}^{-2}$ $\mathrm{day}^{-1}\left(\doteq \mathrm{cm} \mathrm{day}{ }^{-1}\right)$

$L=$ latent heat of vaporization at $T_{0}$ in cal $\mathrm{gm}^{-1}$

$$
Q^{\prime}{ }_{h}-Q_{h}=R^{\prime} Q^{\prime}{ }_{e}-R Q_{\rho}=R^{\prime}{ }_{\rho} E^{\prime} L^{\prime}-R_{\rho} E L
$$

in which $R=$ the Bowen ratio ${ }^{2}=\frac{0.61 P\left(T_{0}-T_{a}\right)}{1,000\left(e_{0}-e_{a}\right)}$

$T_{a}=$ air temperature in degrees $\mathrm{C}$

$e_{0}=$ saturation vapor pressure at $T_{0}$ in $\mathrm{mb}$

$e_{a}=$ vapor pressure of the air in $\mathrm{mb}$

$P=$ atmospheric pressure in $\mathrm{mb}$

$$
Q^{\prime}{ }_{w}-Q_{w}=c \rho E^{\prime} T_{0}^{\prime}-c \rho E T_{0}
$$

in which $\mathbf{c}=$ specific heat of water $\left(\doteq 1 \mathrm{cal} \mathrm{gm}^{-1} \mathrm{deg}^{-1}\right)$ From mass transfer theory, assuming that the wind over both pans is the same and the possible effect of a change in atmospheric stability resulting from the small increase in water temperature in the pan of brine is negligible, it follows that

$$
\frac{E^{\prime}}{E}=\frac{(1-n) e_{0}^{\prime}-e_{a}}{e_{0}-e_{a}}
$$

in which $n=$ ratio of the decrease in saturation vapor pressure caused by salinity to the saturation vapor pressure of pure water. (See fig. 1.). The use of an average figure for water density (equations 4-6) and specific heat (equation 6 ) should be explained. Since the temperature rise in the brine pan is only a few degrees, little error is introducted by assuming that the density of the evaporated water (dissolved solids are not evaporated) is the same for the brine as for water. The variation of specific heat of water with temperature is also small and is neglected.

\footnotetext{
2 Bowen (1926) suggested the use of the ratio of the energy conducted to the atmosphere as sensible heat $\left(O_{h}\right)$ to the energy utilized for evaporation $\left(O_{0}\right)$ as a means of eircumventing the difficulty inherent in measuring $O_{h}$ directly, and presented a formula for computing that ratio from measurements of humidity, air and water temperatures, and atmospheric pressure. An instrument has been developed by Swinbank (1951) for measuring $\bigcap_{h}$ directly, but so far as is known it has not heen used extensively in the field.

Considerable difference of opinion has arisen concerning the validity of the Bowen ratio. This was discussed at length by Anderson (U. S. Geol. Surrey, 1952, pp. 104169), who concluded that the Bowen ratio is satisfactory for use in computing evaporation except when the vapor pressure difference is small.
}

Combining equations (2) to (7), we obtain

$$
\begin{gathered}
\frac{\rho E}{e_{0}-e_{a}}\left\{\left(L^{\prime}+c T_{0}{ }^{\prime}\right)\left[(1-n) e_{0}{ }^{\prime}-e_{a}\right]-\left(L+c T_{0}\right)\left(e_{0}-e_{a}\right)+\right. \\
\left.\frac{0.61 P}{1,000}\left[L^{\prime}\left(T_{0}^{\prime}-T_{a}\right)-L\left(T_{0}-T_{a}\right)\right]\right\}+ \\
1.136 \times 10^{-7}\left[\left(T_{0}{ }^{\prime}+273\right)^{4}-\left(T_{0}+273\right)^{4}\right]=0
\end{gathered}
$$

For any set of assumed values of $T_{0}, T_{a}, P$, and $e_{a}$ and calling $\frac{d Q_{b s}}{d T_{0}}, \frac{d L}{d T_{0}}$, and $\frac{d e_{0}}{d T_{0}}$ constant for the narrow range between $T_{0}$ and $T_{0}{ }^{\prime}$, eq. (8) reduces to the form

$$
E=\frac{k_{1} \Delta T}{(\Delta T)^{2}+k_{2} \Delta T+k_{3}}
$$

in which $\Delta T=T_{0}{ }^{\prime}-T_{0}$

$$
k_{1}, k_{2}, k_{3}=f(n)
$$

Figure 2, which is based on equations (7), (8), and (9), illustrates the manner in which the temperature rise, $\Delta T$, and the evaporation ratio, $E^{\prime} / E$, vary with salinity. The relation between $\mathrm{n}$ and salinity was determined from figure 1. For computational purposes the following conditions were assumed:

$$
\begin{array}{ll}
T_{o}=15^{\circ} \mathrm{C} & \text { relative humidity }=50 \text { percent } \\
T_{a}=15^{\circ} \mathrm{C} & P=1,000 \mathrm{mb}
\end{array}
$$

From figure 2 it will be noted that the evaporation ratio, $E^{\prime} / E$, decreases with increasing salinity, and the temperature rise, $\Delta T$, increases, as might be expected. Both the temperature rise and the evaporation ratio increase more rapidly with an increase in evaporation at high salinities than at low salinities.

With the rate of evaporation from the pan of water and other factors except the water temperature held constant as in figure 2 , the evaporaticn ratio and the temperature rise vary with water surface temperature and salinity in much the same manner as with evaporation and salinity in figure 2.

It is of course possible to construct many graphs similar to figure 2 in which different factors are held constant. However, none would be of practical value because in nature those factors are seldom if ever constant. Thus, for any given set of conditions it is necessary to solve equation (8) which $\mathrm{c} \cdot \mathrm{n}$ be reduced to an equation similar to (9) if the temperature rise is not sufficiently large to invalidate the essumption that the rate of change in emitted long-wave radiation, latent heat of vaporization, and saturation vapor pressure with temperature are constant over the given temperature range. 


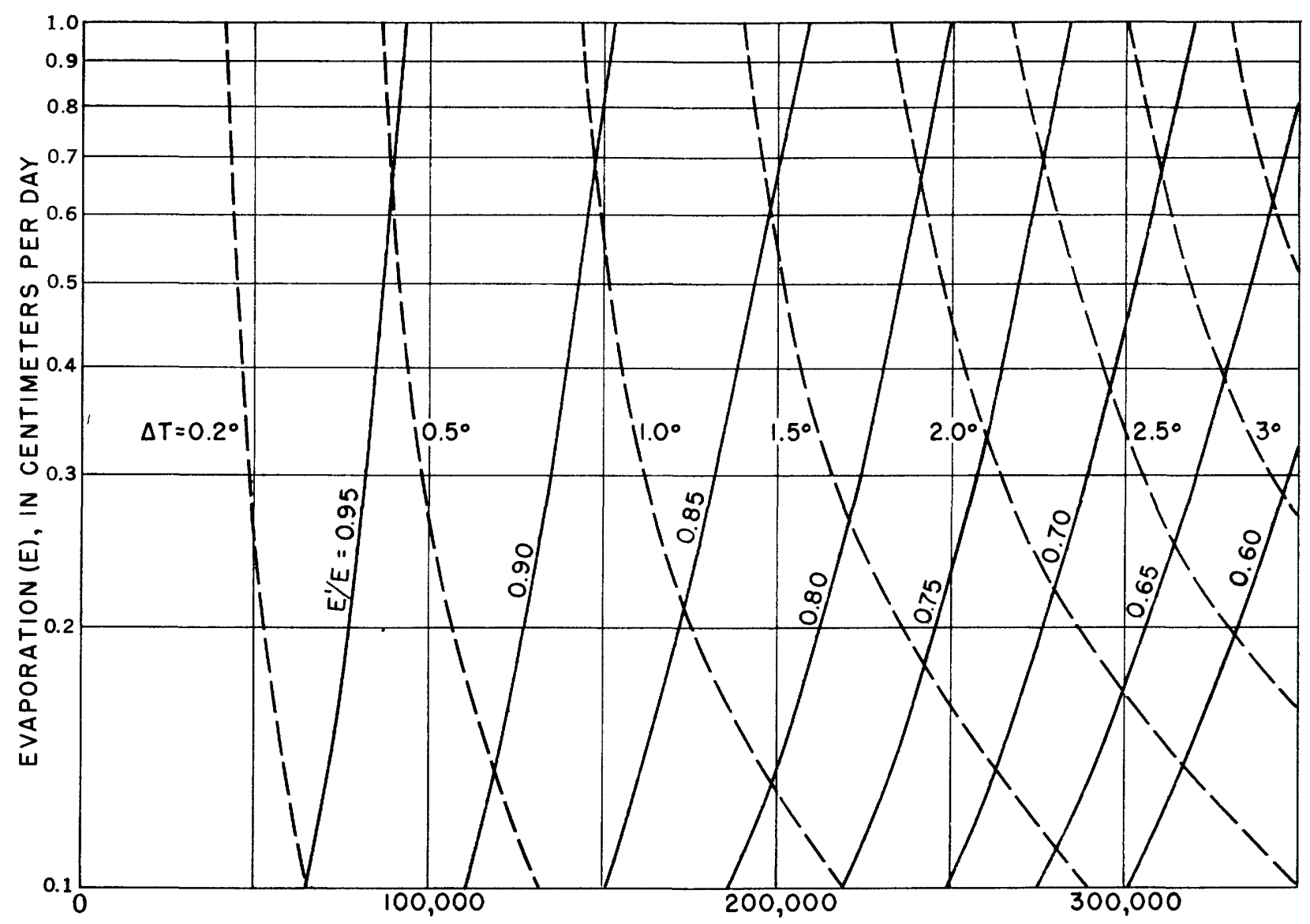

SALINITY, IN PARTS PER MILLION

FIGURE 2.-The variation of evaporation ratio and temperature rise with evaporation rate and salinity.

Under certain conditions, as for example when humidity is high and there is a substantial reduction of saturation vapor pressure owing to salinity, it is quite possible that condensation may occur on the pan of brine while evaporation takes place from the pan of pure water. In the course of an experiment during the winter, Adams (1933) noted that on one occasion evaporation from a pan of frozen water was considerable, but that no evaporation occurred from a pan of brine. The point at which condensation will begin can be determined using equation (8), the condition being that the quantity $(1-n) e_{0}-e_{a}$ be zero, which can most easily be attained at low temperature and high humidity and salinity.

\section{COMPARISON WITH DATA OBTAINED BY ADAMS}

Data are available for an approximate check of figure 2. A laboratory experiment was conducted by Adams (1933) during the period July to October, 1932, to determine the ratio of evaporation from Great Salt Lake brine to evaporation from fresh water. Evaporation rates from pans of brine $(251,000$ p. p. m.) and fresh water were compared. Air temperature and relative humidity were observed only in the morring. During the entire period the evaporation ratio was found to be $0.80-0.82$.

In July, Adams observed that the evaporation from the pan of water was 9 inches $\left(0.74 \mathrm{~cm}\right.$ per $\left.\mathrm{day}^{-1}\right)$ and that the temperature rise was $2^{\circ} \mathrm{C}$. Although the meteorological conditions assumed in figure 2 are not strictly applicable, the figure indicates that for the given salinity and daily evaporation, the computed temperature rise is $2.2^{\circ} \mathrm{C}$ and the evaporation ratio is 0.79 .

During September evaporation was 3 inches $(0.25 \mathrm{~cm}$ day $^{-1}$ ). Adams observed a temperature rise of $1.8^{\circ} \mathrm{C}$. From figure 2 the computed temperature ris? is $1.2^{\circ} \mathrm{C}$ and the evaporation ratio 0.75. Computed temperature rises in July and September check the observed values quite closely, but the computed evaporation retios $(0.79$ and 0.75$)$ are somewhat less than those $(0.8)$ to 0.82) observed by Adams.

An examination of Weather Bureau records at Salt Lake City for the two months in question indicates that relative humidities were probably approximately 30 percent instead of the value of 50 percent used in constructing figure 2. Evaporation ratios decreas? as 
humidity increases, other factors being the same, and it is believed that the apparent differences between computed and observed evaporation ratios are to a large extent caused by the difference in humidity.

\section{SELECTED BIBLIOGRAPHY}

Adams, T. C., 1934, Fvaporation from Great Salt Lake: Bull. Am. Meteorol. Soc., v. 15, p. 35-39.

Bowen, I. S., 1926, The ratio of heat losses by conduction and by evaporation from any water surface: Phys. Rev.. ser. 2, v. 27, p. 779-787.

Lee, C. H., 1927, Discussion of "Evaporation on reclamation projects" by I. E. Houk: Trans. Am. Soc. Civ. Engineers, v. 90, p. $340-343$.

National Research Council, 1928, International Critical Tables: New York, MeGraw Hill, 1st ed., v. 3.
Sutton, O. G., 1949, The application to micrometeorology of the theory of turbulent flow over rough surfaces: Royal Meteorol. Soc. Quart. Jour., v. 75, no. 326, p. 335-350.

Sverdrup, H. U., 1937, On the evaporation from the oceans: Jour. Marine Research, v. 1, no. 1, p. 3-14.

Sverdrup, H. U., Johnson, M. W., and Fleming, R. H., 1942, The oceans: New York, Prentice-Hall.

Swinbank, W. C., 1951, The measurement of vertical transfer of heat and water vapor by eddies in the lower atmosphere: Jour. Meteorology, v. 8, no. 3, p. 135-145.

U. S. Geol. Survey, 195t, Water-loss investigations; Lake Hefner studies, technical report: U. S. Geol. Survey Prof. Paper 269. [Also published as U. S. Navy Electronies Laboratory report $327,1952$.

Young, A. A., 1947, Some recent evaporation investigations: Trans. Am. Geophys. Union, v. 28, no. 2, p. 279-284. 